\title{
DIGITISATION, COPYRIGHT AND THE GLAM SECTOR: CONSTRUCTING A FIT-FOR-PURPOSE SAFE HARBOUR REGIME
}

\author{
Samuel Coad*
}

Copyright law does not currently align with the legitimate activities of galleries, libraries, archives and museums (GLAMS). The GLAM sector plays a central role in collecting and promoting access to cultural works. Increasingly, GLAM institutions are employing innovative digital technologies to expand access to culture and foster greater levels of cultural participation. Despite the utility underlying digitisation, copyright limits the use of digital technologies within the GLAM sphere. This article examines current copyright limitations and demonstrates copyright's significant limiting effect. It argues that reform is necessary to strengthen the right to participate in cultural life and to remedy harms inflicted by the current copyright regime. Creating a fit-for-purpose safe harbour would empower institutions to employ digitisation within a framework of reasonable copyright constraints. Accordingly, this article constructs a potential safe harbor that permits non-commercial GLAM digitisation, while also protecting copyright holders and tikanga Māori. The Copyright Act 1994 is currently under review. New Zealand ought to seize the present reform opportunity to invigorate participation in cultural life and enrich the cultural fabric of society.

\section{INTRODUCTION}

In 2017, the Kremer Museum was officially opened. Visitors to the museum can now freely explore the 74-piece collection of Dutch and Flemish artistic masterpieces - guided by art experts versed in the historical significance of the portraits - in an environment "perfectly optimized to

Submitted for the LLB (Honours) Degree, Faculty of Law, Victoria University of Wellington, 2018. I would like to express thanks to my supervisor, Professor Graeme Austin, for his invaluable advice and support. I would also like to thank Victoria Leachman, Manager Rights at Museum of New Zealand Te Papa Tongarewa, for providing me with her insights on the New Zealand GLAM sphere and the influence of copyright. 
accentuate the colours, brushstrokes, and details in each painting." ${ }^{1}$ Museum lighting is tailored to the needs of each individual and visitors can interact with the paintings from anywhere in the world. ${ }^{2}$ Despite only recently opening, the museum could quickly rival the world's ancient cultural heritage institutions. One unique feature sets this museum apart from others: it exists solely in virtual reality.

The Kremer Museum - while at the upper end of the spectrum - represents an international trend in the cultural heritage sector. Digital technologies are increasingly enabling galleries, libraries, archives and museums (GLAMs) to expand access to, and interaction with, cultural works beyond physical institutional constraints. Projects such as Europeana and Google Art facilitate public access through online databases populated with rich collections of cultural artefacts from the world's GLAM institutions. Archives and libraries are undergoing a similar digital transition by unlocking vast repositories of books, diaries, letters, photographs and other documents for online access. Social media platforms are increasingly employed to engage users and to create interactive forums of cultural participation. ${ }^{3}$ Cumulatively, these technologies have the capacity to promote participation in cultural life and strengthen the role of GLAM institutions in capturing and disseminating the cultural memory of humankind.

Nevertheless, New Zealand's copyright law currently limits the use of digitisation by GLAM institutions. Digitisation falls squarely within the prohibitions enumerated in the Copyright Act 1994. Institutions are consequently barred from digitising cultural works unless authorisation can first be obtained from copyright owners. Relying on prior authorisation generates significant primary and secondary costs and harmfully distorts the culture to which society is exposed. Cultural works thus "languish unused" as copyright ossifies digitisation efforts within the GLAM sphere. ${ }^{4}$

Creating a fit-for-purpose GLAM safe harbour is required to empower institutions to employ digitisation technologies within reasonable copyright constraints. Imposing strict statutory conditions on the safe harbour's operation can adequately protect commercial copyright interests. Reshaping copyright's traditional contours is justified. Legal barriers to digitisation undermine the objective

$1 \quad$ Sarah Burke "A New Museum Exists Solely in VR. What Does that Mean for the Future?" (27 November 2017) Artsy <www.artsy.net>.

2 Burke, above $\mathrm{n} 1$.

3 Georgina Fell "Going Social: A case study of the use of social media technologies by the Museum of New Zealand Te Papa Tongarewa" (Masters Dissertation, Victoria University of Wellington, 2012) at 4-8. See also Rachel Gonzalez "Keep the Conversation Going: How Museums Use Social Media to Engage the Public" (1 November 2017) The Museum Scholar <www.themuseumscholar.org>.

4 Naomi Korn In from the Cold: An assessment of the scope of 'Orphan Works' and its impact on the delivery of services to the public (JISC, June 2009) at 6-7. 
copyright was instituted to protect: the creation and dissemination of cultural works. ${ }^{5}$ Empowering GLAMs to digitise cultural works fosters participation in cultural life and remedies the societal harms currently inflicted by the copyright regime.

This article is comprised of three substantive parts. Part II canvasses the public benefits delivered by GLAM institutions and the role of digitisation in promoting free access to cultural works. It then advances the normative case for reform. Part III examines the current limitations to digitisation imposed by copyright law, and the practical consequences that flow therefrom. Finally, Part IV proposes a fit-for-purpose safe harbour that enables digitisation without prejudicing commercial copyright interests. It also assesses the merits of a copyright safe harbour when compared with the alternative models proposed by reform agencies.

\section{THE ROLE OF GLAM INSTITUTIONS: THE CASE FOR REFORM}

Currently, New Zealand's copyright law does not align with the legitimate activities of galleries, libraries, archives and museums. Unauthorised digitisation is prohibited. As this article establishes in Part III, copyright thus inhibits digitisation, generates primary and secondary costs, and interferes with the public interest mission of the GLAM sector. ${ }^{6}$ Such limits require reconsideration.

Copyright is designed to maximise public welfare by securing the diffusion of creative works for society's enjoyment. ${ }^{7}$ Enabling authors to preferentially exploit their intellectual property achieves this objective as it preserves economic incentives for the generation of new works. ${ }^{8}$ Nevertheless, copyright does not always maximise public welfare. Reforming the scope of copyright is justified when less stringent protection better serves the public interest. ${ }^{9}$ "Fair dealing" provides a useful illustration: limited copying is permitted in furtherance of socially beneficial activities such as

5 Jiarui Liu "Copyright Reform and Copyright Market: A Cross-Pacific Perspective" (2016) 31 Berkeley Tech LJ 1461 at 1508; Susy Frankel Intellectual Property in New Zealand (2nd ed, LexisNexis, Wellington, 2011) at 199-201; and Ian Finch James \& Wells Intellectual Property Law in New Zealand (2nd ed, Brookers, Wellington, 2012) at 225.

6 Ministry of Business, Innovation and Employment Copyright and the Creative Sector: Study of the Role of Copyright and Registered Designs in the Creative Sector in New Zealand (December 2016) at 59. See generally Museum of New Zealand Te Papa Tongarewa Copyright and Museums: Governance, Management and Planning (National Services Te Paerangi Resource Guide Issue no 9, 2013) at 11-15.

7 Liu, above n 5, at 1508; Frankel, above n 5, at 199-201; and Finch, above n 5, at 225.

8 Liu, above $\mathrm{n} 5$, at 1508 .

9 Pamela Samuelson "Justifications for Copyright Limitations and Exceptions" in Ruth Okediji (ed) Copyright Law in an Age of Limitations and Exceptions (Cambridge University Press, Cambridge, 2017) 12 at 29-33; and Anne Lepage "Doctrine and Opinions: Overview of Exceptions and Limitations to Copyright in the Digital Environment" [2003] 1 Copyright Bull 1 at 3-4. 
criticism, review, news reporting, private research and study. ${ }^{10}$ Similarly, copyright "safe harbours" limit the liability of Internet service providers to encourage the development of Internet infrastructure. ${ }^{11}$ In both examples, copyright was purposefully shaped to secure important public policy objectives.

The work of galleries, libraries, archives and museums represents another important sphere in which copyright law ought to be reformed. Digitisation delivers powerful societal benefits. Rather than limiting its use, copyright ought to empower institutions to conduct digitisation. The following sections explore the role of GLAM institutions in greater depth and advance the normative case for reform.

\section{A Public Interest Mission of GLAM Institutions}

Galleries, libraries, archives and museums are a crucial component of society's custodianship of cultural heritage and are responsible for advancing human knowledge by preserving, and promoting access to, the records of humankind. ${ }^{12}$ Capturing and disseminating the cultural memory of peoples and communities across history is a venerable undertaking. ${ }^{13}$ Collectively, GLAMs provide an interface with cultural life, mediated through forums of cultural engagement. ${ }^{14}$ It is through these forums that society can access collections of archival materials, maps, paintings, manuscripts, photographs and other cultural artefacts. ${ }^{15}$

10 Copyright Act 1994, ss 42-43.

11 Jennifer L Hanley "ISP Liability and Safe Harbor Provisions: Implications of Evolving International Law for the Approach Set Out in Viacom v YouTube" (2012) 11 JIBL 183 at 185-186; and Hannibal Travis "Opting Out of the Internet in the United States and the European Union: Copyright, Safe Harbors, and International Law" (2008) 84 Notre Dame L Rev 331 at 348-350.

12 Shannon Wellington "Building GLAMour: Converging practice between Gallery, Library, Archive and Museum entities in New Zealand Memory Institutions" (PhD Thesis, Victoria University of Wellington, 2013) at 24.

13 Shahed Mahmud "History and Re-Convergence of GLAM: A Systematic Literature Review" (Masters Dissertation, Queensland University of Technology, 2014) at 1-2; and Lorcan Dempsey "Scientific, Industrial, and Cultural Heritage: a shared approach - a research framework for digital libraries, museums and archives" Ariadne (online ed, United Kingdom, 12 January 2000).

14 Wellington, above n 12, at 24; Mahmud, above n 13, at 2; Christian Dupont "Libraries, Archives, and Museums in the Twenty-First Century: Intersecting Missions, Converging Futures?" (2007) 8 RBM 13 at 1314; and Margaret Hedstrom "Archives, Memory, and Interfaces with the Past" (2002) 2 Archival Science 21 at 38-41. See also Margaret Hedstrom and John Leslie King "On the LAM: Library, Archive, and Museum Collections in the Creation and Maintenance of Knowledge Communities" (2004) Organisation for Economic Co-operation and Development <http://www.oecd.org>.

15 See Wellington, above $\mathrm{n} 12$, at 24-25. 
Promoting access to, and dissemination of, cultural works delivers powerful societal benefits. Carr - an expert on cultural institutions - perceptively observed: ${ }^{16}$

Cultural institutions ... might more usefully be understood not as places at all, but as the evanescent, constructive moments they contain. We need to understand that libraries, museums, and archives also hold voices, insights, processes, and, in their surprising discoveries, possibilities of mind.

This observation reflects the role of institutions in shaping individual identity. Transformative "constructive moments" can arise by interacting with cultural works. GLAM institutions ultimately foster a climate of cultural vibrancy as individuals can connect with humankind's ancestry, ${ }^{17}$ and develop a deeper understanding of what it means to be human. ${ }^{18}$

Each institution generates significant public benefits. Museums and galleries collect works and cultural heritage objects that portray humanity's progression and reflect society's cultural identity. ${ }^{19}$ The Museum of New Zealand Te Papa Tongarewa Act 1992 illustrates this point: ${ }^{20}$

The purpose of this Act is to establish a National Museum that ... shall provide a forum in which the nation may present, explore, and preserve ... the heritage of its cultures ... in order better-

(a) to understand and treasure the past; and

(b) to enrich the present; and

(c) to meet the challenges of the future.

The Act reveals a central educative focus. Providing forums in which individuals can interpret collections of cultural works facilitates processes of self-identification and learning. ${ }^{21}$ Accessing humanity's cultural ancestry thus "enrich[es] the present" by empowering individuals to develop their own cultural identities based on the "treasure[s of] the past". 22 Museums and galleries also act as

16 David Carr The Promise of Cultural Institutions (AltaMira Press, Walnut Creek (CA), 2003) at 59.

17 Mahmud, above n 13, at 1-2.

18 Wellington, above n 12, at 24; and Elaine Heumann Gurain "A Blurring of the Boundaries" in Gerard Corsane (ed) Heritage, Museums and Galleries: An Introductory Reader (Routledge, London, 2005) 77 at 80-84.

19 Wellington, above n 12, at 26; and Susan A Crane "The Conundrum of Ephemerality: Time, Memory, and Museums" in Sharon MacDonald (ed) A Companion to Museum Studies (Blackwell Publishing, Malden (Massachusetts), 2006) 98 at 98-101.

20 Section 4.

21 Carr, above n 16, at 59.

22 Museum of New Zealand Te Papa Tongarewa Act 1992, s 4. 
vehicles for social progress, ${ }^{23}$ by encouraging critical discourse on events such as the New Zealand Land Wars, the Battle of Gallipoli, New Zealand art, ${ }^{24}$ and feminist movements. ${ }^{25}$ Displaying our shared ancestry draws attention to historical events which society ought to critically examine and learn from, and enables society to better address future challenges. ${ }^{26}$

Libraries and archives deliver similar benefits. Archives preserve the historical record of the communities or states in which they operate. ${ }^{27}$ The original documents held by archival institutions can help to develop a greater understanding of society's historical roots. By way of illustration, Archives New Zealand, Te Rua Mahara o te Kāwanatanga enables individuals to explore the provenance of power through our nation's central constitutional documents; ${ }^{28}$ understand key historical moments, such as the Erebus Disaster $;{ }^{29}$ and experience cultural life as captured by decades of audio-visual works. ${ }^{30}$ Libraries perform a similar function; like other GLAM institutions, libraries are a central mechanism for the diffusion of knowledge. ${ }^{31}$

\section{B Digital Technology: Promoting Access to Culture}

Digitisation technologies amplify the public benefits delivered by GLAM institutions. Online databases enable GLAMs to transcend physical institutional constraints and expand access to collections of cultural works. ${ }^{32}$ Projects such as Europeana and Google Art seek to erode institutional barriers and enhance access to culture by constructing online repositories of the world's books,

23 Emmanuel N Arinze "The Role of the Museum in Society" (public lecture at the National Museum of Guyana, Georgetown, 17 May 1999).

24 Museum of New Zealand Te Papa Tongarewa "Discover the Collections" <www.tepapa.govt.nz>.

25 Auckland Museum "Are We There Yet? Women and Equality in Aotearoa" <www.aucklandmuseum.com>.

26 Arinze, above n 23.

27 Wellington, above n 12, at 26.

28 Archives New Zealand Te Rua Mahara o te Kāwanatanga "Provenance of Power - Constitutional Documents" <http://archives.govt.nz>.

29 Archives New Zealand Te Rua Mahara o te Kāwanatanga "Erebus Remembered: Flight TE901" $<$ http://archives.govt.nz>.

30 Archives New Zealand Te Rua Mahara o te Kāwanatanga "Audio Visual Archives" < http://archives.govt.nz>.

31 Wellington, above n 12, at 26.

32 Emily Hudson and Andrew T Kenyon "Digital Access: The Impact of Copyright on Digitisation Practices in Australian Museums, Galleries, Libraries and Archives" (2007) 30 UNSW Law Journal 12 at 21; Susan J Drucker and Gary Gumpert "Museums Without Walls: Property Rights and Reproduction in the World of Cyberspace" in Susan Tiefenbrun (ed) Law and the Arts (Greenwood Press, Westport (Connecticut), 1999) 47 at 47-49; and Ministry of Business, Innovation and Employment, above n 6, at 58. 
artworks, photographs and other cultural artefacts. ${ }^{33}$ At the time of writing, Europeana contains 58,794,452 works from over 3,500 European institutions. ${ }^{34}$ Digitisation has the capacity to create a single online intellectual space for cultural works $: 35$

It's no longer necessary to visit Sydney to see Fire's On - or the Rijksmuseum to see the Rembrandts, or

New York for the Museum of Modern Art. With a laptop you can conjure a virtual walk-through ... With

a tablet device, you can zoom in on The Starry Night and see Vincent van Gogh's ecstatic swirls of yellow

paint and those places where the canvas is bare.

Digitisation occurs through a range of mediums. Institutions are gradually constructing online databases of analogue collection items. ${ }^{36}$ For example, Archives New Zealand employs limited digitisation of collections such as war casualty forms, papers from former Crown Ministers and documents surrounding the women's suffrage movement. ${ }^{37}$

Social media platforms provide another example. ${ }^{38}$ Global access is enhanced through social media: a study on social media services found that "online communities are accessed by 67 per cent of the global online population." 39 Famous institutions such as the Met, the Louvre and MoMA use social media to provide online access to cultural works. ${ }^{40}$ Indeed, MoMA has an Instagram following of over 4.5 million users, ${ }^{41}$ while the Met's Facebook page reaches over 92 million users. ${ }^{42}$ Social media platforms are unique - they enable participants to engage with cultural works in new ways,

33 At the launch of Europeana in 2008, the Council of Ministers stated "Digitisation and online accessibility ... help to democratise access and to develop the information society and the knowledge-based economy": Europeana Europeana Strategic Plan 2011-2015 (January 2011) at 3.

34 Europeana "Europeana Collections" <www.europeana.eu>.

35 Matthew Westwood "Google Cultural Institute teams up with world's galleries, museums" The Weekend Australian (online ed, New South Wales, 17 September 2016) at 1-2.

36 Hudson and Kenyon "Digital Access", above n 32, at 21.

37 Archives New Zealand Te Rua Mahara o te Kāwanatanga "Exhibitions" < http://archives.govt.nz>.

38 Antonio Padilla-Meléndez and Ana Rosa del Águila-Obra "Web and social media usage by museums: Online value creation" (2013) 33 IJIM 892 at 892-895.

39 Adrienne Fletcher and Moon J Lee "Current social media uses and evaluations in American museums" (2012) 5 MMC 505 at 507. See also The Nielsen Company Global Faces and Networked Places: A Nielsen report on Social Networking's New Global Footprint (March 2009) at 2.

40 Gonzalez, above n 3.

41 The Museum of Modern Art (@themuseumofmodernart) Instagram <www.instagram.com>.

42 Gonzalez, above n 3; and Anand Giridharadas "Museums See Different Virtues in Virtual Worlds" The New York Times (online ed, New York, 7 August 2014) at 2-3. 
communicate with institutions directly, ${ }^{43}$ discuss works with the public, and participate in an interactive educative process. ${ }^{44}$

Moreover, digital repatriation of cultural property is a powerful tool for indigenous peoples seeking to reassert control over property alienated or appropriated through colonialism. ${ }^{45}$ Physically dispersed cultural property can be reassembled in virtual form where physical repatriation is unavailable. ${ }^{46}$ Māori iwi Te Aitanga-a-Hauiti collaborated with the University of Cambridge to construct a database compiling images, texts, recordings and videos of their taonga. ${ }^{47}$ Similarly, Te Papa has initiated a project that aims to use 3D imaging technology to create virtual copies of taonga for the benefit of Māori. ${ }^{48}$ Amassing digital surrogates of taonga has the potential to reinvigorate inter-iwi relationships, foster critical engagement with Māori history ${ }^{49}$ and provide a focal point for cross-cultural collaboration and research. ${ }^{50}$

\section{Normative Case for Reform}

Given their central role in providing an interface with cultural life, society can justify cutting GLAM institutions some copyright slack. Promoting free online access to cultural works ought to be encouraged. Instead, as noted above, copyright inhibits digitisation projects and undermines the public interest missions of GLAM institutions. Creating a GLAM safe harbour is required to empower institutions to take up digital technologies within a framework of reasonable copyright constraints. Reform is justified on two normative bases: promoting participation in cultural life and addressing copyright harms. These bases are discussed in turn.

43 Fletcher and Lee, above n 39, at 508.

44 Gonzalez, above n 3.

45 Wayne Ngata, Hera Ngata-Gibson and Amiria Salmond "Te Ataakura: Digital taonga and cultural innovation" (2012) 17 J Material Cult 229 at 230.

46 At 231.

47 At 229 .

48 Michelle Horwood "Going Digital in the GLAM Sector: ICT innovations \& collaborations for taonga Māori" in Hēmi Whaanga, Te Taka Keegan and Mark Apperley (eds) He Whare Hangarau Māori: Language, Culture and Technology (University of Waikato, Hamilton, 2017) 149 at 151-152.

49 Ngata, Ngata-Gibson and Salmond, above n 45, at 241.

50 Paul Resta and others "Digital Repatriation: Virtual Museum Partnerships with Indigenous Peoples" (paper presented to International Conference on Computers in Education, Auckland, December 2002) at 2. 


\section{Strengthening the right to participate in cultural life}

International law guarantees individuals the right to freely participate in cultural life. ${ }^{51}$ Participation is open-textured and includes the right to choose one's cultural identity through immersion in cultural life; to freely engage with forms of cultural expression; ${ }^{52}$ to access art, the humanities and cultural heritage; and to acquire cultural knowledge. ${ }^{53}$ Dignity interests are advanced as access to culture fosters societal growth driven by the "full harmonious development of all its members and the free play of their creative faculties. ${ }^{54}$

Digitisation has the capacity to strengthen the right to participate in cultural life. Currently, access is inherently fragmented as collection items are housed across discrete institutions. ${ }^{55}$ Fragmentation creates an inequality of access: those without access to these institutions are deprived of the opportunity to interact with valuable cultural products. ${ }^{56}$ Online access would ensure that individuals could interact with digital surrogates of cultural works "irrespective of the physical location, specific characteristics and abilities of the user, or the physical location of the resources. ${ }^{\text {57 }}$ Digitisation could also foster broader cultural engagement. Currently, upper socio-economic groups have higher rates of cultural participation than lower socio-economic groups. ${ }^{58}$ A recent United Kingdom study found that for museum and gallery attendance "there is a 26.5 percentage point gap" between upper and lower socio-economic groups. ${ }^{59} \mathrm{New}$ forms of digital engagement extend participation beyond traditional

51 Universal Declaration of Human Rights GA Res 217A (1948), art 27; and International Covenant on Economic, Social and Cultural Rights 993 UNTS 3 (opened for signature 16 December 1966, entered into force 3 January 1976), art 15(1)(a).

52 UN Committee on Economic, Social and Cultural Rights General Comment No 21: Right of everyone to take part in cultural life (art 15, para 1(a), of the International Covenant on Economic, Social and Cultural Rights) UN Doc E/C.12/GC/21 (21 December 2009) at 3-5.

53 United Nations Educational, Scientific and Cultural Organization Recommendation on Participation by the People at Large in Cultural Life and their Contribution to It XIX (26 November 1976) at [1]-[3].

54 At [1].

55 See Drucker and Gumpert, above n 32, at 47-51.

56 Howard Besser "The Changing Role of Photographic Collections with the Advent of Digitization" in Katherine Jones-Garmil (ed) The Wired Museum: Emerging Technology and Changing Paradigms (American Association of Museums, Washington DC, 1997) 115 at 117-118.

57 Oleg Missikoff "Assessing the Role of Digital Technologies for the Development of Cultural Resources as Socio-Economic Assets" in Ian Russell (ed) Images, Representations and Heritage: Moving Beyond Modern Approaches to Archaeology (Springer, Boston, 2006) 139 at 153.

58 Harry Armstrong and others Experimental Culture: A horizon scan commissioned by Arts Council England (Arts Council England, March 2018) at 12.

59 At 12. 
"elite" methods of cultural consumption. Digital interactivity makes engaging with cultural life a more unique and personalised experience. ${ }^{60}$ Users can zoom in, juxtapose individually selected works, research the history behind a work and make full use of the digital environment. ${ }^{61}$ Institutions report that virtual access has already increased demand for digitally accessible works and heightened engagement with the GLAM sector. ${ }^{62}$

Intellectual property regimes ought to coexist with human rights law. ${ }^{63}$ Reform is justified in order to strengthen participation in cultural life and maximise the benefits provided by GLAM institutions.

\section{Distorted access to culture: addressing copyright harms}

Justifications for reform do not rest solely on maximising the role of GLAM institutions. Strengthening the ability to digitise cultural works is also necessary to remedy societal harms inflicted by the copyright regime. Currently, copyright detrimentally influences the selection of works for digitisation. Online databases ought to contain works selected based on their inherent cultural worth. Cultural works are instead selected based on the relative ease of copyright compliance. ${ }^{64}$ As one academic commented: ${ }^{65}$

What is required is a growing public awareness to the fact that in digital domains, copyright law is becoming the central centrifugal force through which cultural preservation, cultural heritage and historical truthfulness are being weaved into our social and individual spheres.

Copyright's influence is significant. Its effect is evidenced by the observable "digital skew". ${ }^{6}$ Virtual databases of cultural works suffer from an inherent bias: historic works are disproportionately

60 Besser, above n 56, at 119.

61 At 119

62 Ministry of Business, Innovation and Employment, above n 6, at 58; and Hudson and Kenyon "Digital Access", above n 32, at 21.

63 See generally Impact of the Agreement on Trade-Related Aspects of Intellectual Property Rights on human rights: Report of the High Commissioner UN Doc E/CN.4/Sub.2/2001/13 (27 June 2001); and Audrey R Chapman "Approaching intellectual property as a human right (obligations related to Article 15(1)(c))" (2001) 35(3) Copyright Bull 4 at 14-17 and 30.

64 Jean Dryden "Copyright issues in the selection of archival material for internet access" (2008) 8 Archival Science 123 at $130-134$.

65 Guy Pessach "Museums, Digitization and Copyright Law: Taking Stock and Looking Ahead" (2007) 1 J Int Media and Ent Law 253 at 283.

66 Emily Hudson and Andrew Kenyon "Without Walls: Copyright Law and Digital Collections in Australian Cultural Institutions" (2007) 4 SCRIPT-ed 197 at 200. 
overrepresented whilst contemporary copyright-protected works are curiously absent. ${ }^{67}$ Part III examines in greater depth how copyright interferes with the selection of works for digitisation. For now, it is sufficient to note that copyright is responsible for generating the digital skew. This has significant consequences.

The digital skew distorts the culture to which society is exposed. Online databases do not accurately represent humanity's cultural progression or contemporary values and beliefs. Participation in cultural life includes the right to access the cultural values underpinning society, the right to enjoy the benefits of culture and the right to play a role in cultural development and progression. ${ }^{68}$ The digital skew prevents the realisation of these rights. Overrepresentation of historic works creates a profound time lag. Historically, it was European men who curated collections: cultural works were only retained when they received the imprimatur of the curators. Modern society is thus digitally immersed in collections imbued with the culture, beliefs and ideologies of an imperial and colonial past. ${ }^{69}$ Cultural identity often pivots around the culture to which we are exposed. Experiencing culture through an outdated historic lens has the capacity to distort society's cultural identity and re-emphasise historic trends long since abandoned. ${ }^{70}$

Reform is required. Public interest considerations justify recalibrating the relationship between GLAMs and copyright owners to enable more expansive digitisation. To achieve this, it is necessary to examine current copyright limits in greater depth.

\section{LIMITS TO DIGITISATION IMPOSED BY COPYRIGHT}

Institutions report that copyright limits their ability to take up digital technologies to promote access to cultural works. ${ }^{71}$ Such limits now require greater scrutiny in light of the view that copyright ought to better recognise the public interest underlying GLAM digitisation. Creating a fit-for-purpose safe harbour would realign copyright law with the legitimate activities of GLAM actors and grant

67 Victoria Stobo "Copyright, Digitisation and Risk: Taking Risks with Archive Collections" in Ronan Deazley and Andrea Wallace (eds) Copyright and Cultural Memory: Digital Conference Proceedings (CREATe Working Paper 2017/03, March 2017) 26 at 27; and Hudson and Kenyon "Without Walls", above n 66, at 208 .

68 See generally United Nations Educational, Scientific and Cultural Organization, above n 53, at [1]-[3].

69 Simon Tanner "Threads of Culture, Threads of Discourse" in Ronan Deazley and Andrea Wallace (eds) Copyright and Cultural Memory: Digital Conference Proceedings (CREATe Working Paper 2017/03, March 2017) 77 at 88.

70 At 88 .

71 Ministry of Business, Innovation and Employment, above n 6, at 59; Museum of New Zealand Te Papa Tongarewa Copyright and Museums: Governance, Management and Planning, above n 6, at 26; and Hudson and Kenyon "Without Walls", above n 66, at 209. 
greater freedom to employ digitisation within reasonable copyright constraints. Crafting a safe harbour regime first requires a more nuanced understanding of copyright's current limits on digitisation. Disaggregating the complex relationship between copyright and GLAMs reveals copyright to have a significant limiting effect. The following sections explore these limits in greater depth.

\section{A The Current Statutory Position}

Currently, New Zealand's copyright system does not contain any special rules governing digitisation by not-for-profit cultural institutions. Recourse to New Zealand's codified copyright exceptions may provide limited relief where the purpose of copying is solely to preserve cultural artefacts or to promote research and education. But where digitisation is directed at enabling free public access to cultural works, these exceptions are too narrow to be of use.

Libraries and archives benefit from narrow copyright exceptions that reflect the utility underlying the services they provide. ${ }^{72}$ Museums are not expressly mentioned but may receive indirect protection for activities that fall within the scope of the legislative definition of an "archive". ${ }^{73}$ Limited copying is permitted but, these exceptions are not sufficiently broad to encompass mass digitisation. Qualifying institutions are confined to copying works for the purposes of research, education and preservation. ${ }^{74}$ Copying is undertaken in response to user requests and only a "reasonable proportion" of any literary, dramatic or musical work may be copied. ${ }^{75}$ Resultant digitised items can only be communicated online pursuant to a copyright licence. ${ }^{76}$ Mass digitisation therefore falls outside the scope of these copyright exceptions.

"Fair dealing" does not alter this legal position. New Zealand's copyright system excuses unauthorised copying where it is "fair" and conducted for the purposes of criticism, review, news reporting, research or private study. ${ }^{77}$ Promoting access to cultural works through digitisation does not fall within the scope of the fair dealing defences. Mass copying is also unlikely to be considered

72 Copyright Act, ss 50-57A.

73 Susan Corbett "Copyright Norms and Flexibilities in the Digitisation Practices of NZ Museums" (2011) 29 LIC 55 at 59. "Archive" is defined in s 50(1)(a)(vi) of the Copyright Act as: "any collection of documents ... of historical significance or public interest that is in the custody of ... a body ... that does not keep and maintain the collection for the purpose of deriving a profit".

74 Copyright Act, ss 51(3), 52(3) and 55.

75 Copyright Act, s 51(1).

76 Copyright Act, s 56A. See also Frankel, above n 5, at 370.

77 Copyright Act, ss 42-43. 
"fair" as works are copied in their entirety and can often be reasonably obtained through licence arrangements. ${ }^{78}$

Consequently, GLAM institutions seeking to digitise cultural works are subject to the general copyright framework. This has significant legal consequences.

\section{B Legal Barriers to Digitisation}

Digitisation is in tension with the proscriptions contained in copyright law. Without express authorisation or the shelter of a statutory exception, digitisation infringes copyright. ${ }^{79}$ Four exclusive economic rights are engaged: the right to copy the work, and the rights to perform, play and show the work in public. ${ }^{80}$

Digitisation requires extensive direct and indirect copying. Direct copying occurs throughout the digitisation process. Artistic works are photographed, sculptures and other 3D works are virtually reconstructed, and literary works are scanned. All of these acts constitute "copying" as they involve identically reproducing the entirety of a copyright-protected work. ${ }^{81}$ Indirect copying also occurs when institutions reproduce complex works in which multiple copyright interests subsist. Lord Hoffmann famously used the example of a newspaper to illustrate this point: ${ }^{82}$

There are several copyrights which may simultaneously subsist in the contents of a newspaper. Each of the articles is a literary work in which ... copyright may subsist ... Similarly, the drawings and photographs are artistic works. In addition, the publisher is entitled to a copyright in the typographical arrangement of the published edition[.]

Digitising films, sounds recordings, literary pieces and other complex works involves extensive indirect copying. This is prohibited without authorisation.

78 See Copyright Act, s 43(3).

79 Hudson and Kenyon "Without Walls", above n 66, at 203-204; and Corbett "Copyright Norms and Flexibilities in the Digitisation Practices of NZ Museums", above n 73, at 58.

80 Copyright Act, s 16(1)(a) and (c)-(e).

81 Copyright Act, s 2 definition of "copying": "means, in relation to any description of work, reproducing, recording, or storing the work in any material form (including any digital format), in any medium and by any means". According to case law, the reproduction must be of the entire work or a substantial part; there must be sufficient objective similarity; and there must be a causal connection between the copyright work and the infringing work: Wham-O MFG Co v Lincoln Industries [1984] 1 NZLR 641 (CA) at 666.

82 Newspaper Licensing Agency Ltd v Marks and Spencer plc [2001] UKHL 38, [2003] 1 AC 551 at [4]. 
Providing virtual access to copyright-protected works infringes further exclusive rights. Literary, dramatic, musical and artistic works cannot be performed in public without authorisation. ${ }^{83}$ Similarly, sound recordings, films or communication works cannot be played or showed in public without consent. ${ }^{84}$ Digitisation infringes these proscriptions. Virtual databases extend access to the wider public and necessarily involve performing, playing and showing copyright works. For example, providing online access to archived film collections requires GLAMs to enable individuals to play films.

Copyright thus limits the permissible scope of GLAM digitisation. Public domain works provide one avenue, as institutions are free to draw on the intellectual commons and exploit out-of-copyright works. Yet, relying exclusively on the public domain deprives virtual databases of the cultural vibrancy they could enjoy if populated by modern - but still copyright-protected - artworks, films, literary works and other cultural artefacts. Consequently, GLAM institutions are required to obtain permission from copyright owners to enable more expansive digitisation. Even in this space, copyright continues to exert a significant influence leading to practical consequences for GLAM institutions.

\section{Practical Consequences of Copyright Barriers}

Digitisation is prohibited unless authorisation is obtained. Typically, GLAMs use two legal devices to ensure digitisation is copyright compliant: assignments and non-exclusive licences. ${ }^{85}$ Yet, relying on these devices generates significant practical consequences. As the analysis below seeks to establish, licensing creates significant primary and secondary costs. Collectively, these implications further limit the ability of GLAM institutions to digitise and promote access to cultural works.

\section{GLAM reliance on assignments and licences}

GLAM institutions rely heavily on assignments and licences. Assignment is the more powerful legal tool. ${ }^{86}$ Upon assignment, the institution acquires exclusive rights over the work to the extent conferred by the assignment's terms. ${ }^{87}$ Assignment is rare and is more commonly used by "social history" institutions, such as archives. ${ }^{88}$ Cultural works in the social history sphere are often devoid

83 Copyright Act, s 32(1).

84 Copyright Act, s 32(2).

85 Hudson and Kenyon "Digital Access", above n 32, at 23-27.

86 At 25-27.

87 Copyright Act, ss 113-114. See also Frankel, above n 5, at 210.

88 Hudson and Kenyon "Digital Access", above n 32, at 25-26. 
of inherent economic value and were not created for the purposes of commercial exploitation. ${ }^{89}$ Authors of works such as letters, diaries, political papers and surveying charts are thus - assuming such authors can be found - generally comfortable with transferring copyright, unless confidentiality or privacy is at stake. ${ }^{90}$

Authors of commercial works have strong economic interests and instead rely on non-exclusive licences. ${ }^{91}$ Licensing enables copyright holders to retain control over their works and derive a greater income than could be achieved by assignment. ${ }^{92}$ Non-exclusive licences are thus regularly utilised by GLAM institutions operating in commercial fields such as the fine arts. ${ }^{93}$ Te Papa is an apt example: the museum uses a standard non-exclusive licence for non-commercial digitisation of copyrightprotected works. ${ }^{94}$

\section{Primary costs of the licensing framework}

The licensing framework generates primary costs due to the unique context in which GLAMs operate. Typically, copyright works are inherently fungible. ${ }^{95}$ Prospective licensees who are dissatisfied with paying for an expensive copyright licence can switch to a substitute work in respect of which a lesser fee is charged. The GLAM context is different. Institutions seeking to digitise the entirety of their collections must obtain licences for the particular works in question. A gallery seeking to digitise Rita Angus' famous "Rutu" or a library seeking to distribute a digital version of Witi Ihimaera's novel The Trowenna Sea is not free to switch to a substitute product. Copyright owners in the GLAM sphere thus enjoy an economic monopoly over their works and a correlative power to extract high licence fees.

89 Hudson and Kenyon "Without Walls", above n 66, at 203-204; and Corbett "Copyright Norms and Flexibilities in the Digitisation Practices of NZ Museums", above n 73, at 209.

90 Hudson and Kenyon "Digital Access", above n 32, at 26.

91 At $25-27$.

92 See generally Hudson and Kenyon "Digital Access", above n 32, at 24-26.

93 At $25-26$

94 Museum of New Zealand Te Papa Tongarewa "Collection - Non-commercial Museum Use Copyright Letter and Form" provided by Victoria Leachman (Manager Rights at Museum of New Zealand Te Papa Tongarewa).

95 See generally Nichols $v$ Universal Pictures Corporation 45 F 2d 119 (2d Cir 1930) at 121; and Bleiman v News Media (Auckland) Ltd [1994] 2 NZLR 673 (CA) at 677-679. 
High licence fees are not necessarily the norm. Copyright owners often provide unremunerated licences to the not-for-profit cultural heritage sector. ${ }^{96}$ Te Papa is a useful illustration: 77 per cent of copyright licences for fine artworks permit digitisation without charging licence fees. ${ }^{97}$ Unremunerated licences are likely offered to GLAM institutions to support their public interest missions of promoting access to cultural works. ${ }^{98}$ Authors may also derive secondary benefits from digitisation such as increased exposure and indirect financial gains. ${ }^{99}$ Fees are however often imposed where the copyright owner is a member of a collective licensing body. ${ }^{100}$ Collective bodies rarely waive fees and instead opt to charge for online uses of copyright works. ${ }^{101}$ Similarly, famous authors can capitalise on their international prestige and extract licence fees for digital uses of their creative works. ${ }^{102}$

Licence fees pose a significant barrier to digitisation, even when fees are low. GLAMs typically labour under restrictive budgets. Moreover, digitisation projects do not normally generate revenue. ${ }^{103}$ Consequently, GLAMs have little money to spend on copyright licences and no means of directly recouping their expenditure. Licensing fees may be affordable on an individual basis, yet fees become prohibitively expensive when "aggregated within one project."104 Hundreds of thousands of individual licences may be required to undertake copyright compliant digitisation. A recent study illustrates this point: ${ }^{105}$

96 Hudson and Kenyon "Digital Access", above n 32, at 25; and Museum of New Zealand Te Papa Tongarewa Copyright and Museums: Governance, Management and Planning, above n 6, at 15.

97 Email from Victoria Leachman (Manager Rights at Museum of New Zealand Te Papa Tongarewa) to Samuel Coad regarding licensing practices in New Zealand GLAM institutions (8 August 2018); and email from Victoria Leachman (Manager Rights at Museum of New Zealand Te Papa Tongarewa) to Samuel Coad regarding statistics on Te Papa's copyright licensing practices (30 August 2018).

98 Hudson and Kenyon "Digital Access", above n 32, at 25.

99 Museum of New Zealand Te Papa Tongarewa Copyright and Museums: Governance, Management and Planning, above n 6, at 15; and Hudson and Kenyon "Digital Access", above n 32, at 25.

100 Leachman email regarding licensing practices in New Zealand GLAM institutions, above n 97.

101 Leachman email regarding licensing practices in New Zealand GLAM institutions, above n 97.

102 Leachman email regarding licensing practices in New Zealand GLAM institutions, above n 97.

103 Leachman email regarding licensing practices in New Zealand GLAM institutions, above n 97.

104 Hudson and Kenyon "Digital Access", above n 32, at 24.

105 At 24. 
...one interviewee seeking an astronomical image for an exhibition noted that excellent material was available from a particular source, but would cost US\$400 per image and said "we might do it once, but if you've got 3000 images in your show you can't."

Pursuing copyright licences for the images in the above example would cost that institution USD 1.2 million. Due to the aggregate cost of purchasing licences, some GLAM institutions extract themselves from negotiations in which copyright owners seek to charge fees for digitisation. ${ }^{106}$

\section{Secondary costs of the licensing framework}

Secondary costs are also incurred. Copyright is not a registration system. ${ }^{107}$ Collective copyright licensing bodies do exist for common works such as paintings, music and literary works. ${ }^{108}$ Locating copyright owners is still however difficult, particularly in social history institutions such as archives where there may be no clear records available. ${ }^{109}$ Cultural works such as diaries, maps and photographs are a prime target for digitisation as they provide rich cultural vibrancy to virtual databases. Yet, these works are often not created with an expectation that future institutions will be interested in locating the author. ${ }^{110}$ Transaction costs are thus high, as significant resources are required to locate individual copyright owners. ${ }^{111}$ New Zealand institutions report that this process sometimes requires years of research. ${ }^{112}$

Negotiating licensing terms is also expensive. ${ }^{113}$ Whilst many institutions employ standard licensing terms, there is no guarantee that these terms will be accepted. Disputes can arise over the type of licence sought or the scope of the licence granted. Copyright holders sometimes question the

106 Leachman email regarding licensing practices in New Zealand GLAM institutions, above n 97.

107 Frankel, above n 5, at 182.

108 Museum of New Zealand Te Papa Tongarewa Copyright and Museums: Governance, Management and Planning, above n 6, at 13 .

109 Susan Corbett "Orphan Works" [2010] NZLJ 88 at 88-89.

110 See generally Ministry of Business, Innovation and Employment, above n 6, at 59; and Hudson and Kenyon "Digital Access", above n 32, at 39-41.

111 Rosemary Chandler "Putting Fair Use On Display: Ending the Permissions Culture in the Museum Community" (2016) 15 Duke L \& Tech Rev 60 at 73-74; Patricia Aufderheide and others Copyright, Permissions, and Fair Use among Visual Artists and the Academic and Museum Visual Arts Communities: An Issues Report - A Report to the College Art Association (February 2014) at 54-55; Frankel, above $\mathrm{n}$ 5, at 179; Hudson and Kenyon "Digital Access", above n 32, at 25; and Hudson and Kenyon "Without Walls", above $\mathrm{n} 66$, at 207.

112 Ministry of Business, Innovation and Employment, above n 6, at 59.

113 Hudson and Kenyon "Digital Access", above n 32, at 25. 
extent to which online digitisation represents truly "non-commercial" conduct, ${ }^{114}$ or are uncomfortable with the breadth of the licence. ${ }^{115}$ In these circumstances, copyright owners require further negotiation or prefer to decide on a case-by-case basis. ${ }^{116}$ Faithful reproduction of the work is also typically required by the terms of the licence. Consultation with the creator will usually be required where the institution intends to make alterations to the copyrighted work. ${ }^{117}$ Alterations such as cropping, overprinting and watermarking may distort the work such that the creator's moral right to object to derogatory treatment is engaged. ${ }^{118}$ Moral rights protect the author against uses of their copyright work prejudicial to the author's reputation. Therefore, during the licensing process institutions typically seek written consent from creators regarding the scope of permissible uses of the copyright work. Protracted licensing negotiations further increase costs.

Complying with copyright licences requires further spending. GLAM institutions typically establish digital copyright information management systems to track copyright licences and secure compliance with the terms upon which works are licenced. ${ }^{119}$ Information management systems involve significant development and running costs, especially as employees need to be trained in copyright law basics to manage these systems. ${ }^{120}$ Virtual safeguards are also costly. Protective measures include preventing right-click copy functionality on online databases, embedding copyright information into images via digital watermarks and publishing low-resolution images to dissuade commercial use of digitised works. ${ }^{121}$ Compliance costs undermine the ability of GLAMs to undertake digitisation.

114 At 24 .

115 Leachman email regarding licensing practices in New Zealand GLAM institutions, above n 97.

116 Leachman email regarding licensing practices in New Zealand GLAM institutions, above n 97.

117 Museum of New Zealand Te Papa Tongarewa Copyright and Museums: Governance, Management and Planning, above $\mathrm{n}$ 6, at 15.

118 At 15.

119 Hudson and Kenyon "Without Walls", above n 66, at 207; and Hudson and Kenyon "Digital Access", above n 32 , at 38 and 43 .

120 Hudson and Kenyon "Digital Access", above n 32, at 38.

121 Museum of New Zealand Te Papa Tongarewa Copyright and Museums: Governance, Management and Planning, above n 6, at 14-15. 


\section{Copyright and the Selection of Works for Digitisation}

As noted in Part II, copyright interferes with the selection of works for digitisation and ultimately contributes to the creation of the digital skew. Copyright's interference - and the means by which this interference occurs - requires more detailed consideration.

Cultural works are often selected for digitisation based on ease of copyright compliance rather than inherent cultural worth. ${ }^{122}$ Public domain works are thus preferred as they are no longer subject to copyright protection. ${ }^{123}$ This explains why historic works are over-represented in virtual databases. Indeed, a recent study of Canadian archival institutions reported that 42 per cent of repositories solely digitised public domain works or works where the institution owned the copyright. ${ }^{124}$ Modern works are under-represented because of difficulties in complying with the copyright regime. Two case studies illustrate this point: complex works and orphan works.

Digitising complex cultural works is onerous. Institutions typically eschew works in which multiple copyright interests subsist simultaneously. ${ }^{125}$ Films are one example: the film, music and script are all separate copyright interests. ${ }^{126}$ Consent must be obtained from each copyright owner before digitisation can occur. Works such as sound recordings, films and dramatic works consequently have a scarce online presence due to the difficulties identifying underlying copyright works and acquiring licences. ${ }^{127} \mathrm{~A}$ recent Canadian study revealed the extent to which copyright deters institutions from digitising complex works. Of the 154 institutions surveyed, only 26 digitised sound recordings and 14 digitised films. ${ }^{128}$ Conversely, 147 institutions digitised photographs and 87 digitised literary works. ${ }^{129}$

Orphan works provide another illustration of the extent to which copyright interferes with the selection of works for digitisation. "Orphan" is the term ascribed to works whose copyright owner

122 Jean Dryden, above n 64, at 130.

123 Museum of New Zealand Te Papa Tongarewa Copyright and Museums: Governance, Management and Planning, above n 6, at 14. Academic studies reveal that this is an international trend: see Caroline R Arms "Getting the Picture: Observations from the Library of Congress in Providing Access to Pictorial Images" (1999) 48 Libr Trends 379; and Elizabeth Shepard "Digitizing a photographic collection in a midsize repository: a case study" (2004) 4 J Arch Organ 133.

124 Jean Dryden, above n 64, at 133-134.

125 At 130 .

126 Copyright Act, s 2. See also Frankel, above n 5, at 223.

127 Hudson and Kenyon "Without Walls", above n 66, at 209.

128 Jean Dryden, above n 64, at 130.

129 At 130 
cannot be identified or located. ${ }^{130}$ Typically, these are social history works such as diaries, letters, maps and photographs. Discovering the provenance of these works can be a futile exercise institutions report that years of research can be expended with no success. ${ }^{131}$ Risk management strategies are a viable option. After conducting a reasonable search for the owner, institutions could choose to digitise and incur the risk of copyright liability. The risk of liability is often small. Social history works are typically not created for commercial exploitation. ${ }^{132}$ It is therefore unlikely the lost owner will emerge and enforce their economic rights. Nevertheless, GLAM institutions are wary of copyright risks and prefer to be certain of copyright compliance. ${ }^{133}$ Abandoning orphan works and focusing on works for which licences are obtainable minimises the liability risk. ${ }^{134}$ Vast collections of orphan works thus remain undigitised. For example, data from 503 United Kingdom cultural institutions revealed that the number of orphan works held in their collections exceeded 13 million. ${ }^{135}$

\section{CRAFTED FIT-FOR-PURPOSE SAFE HARBOUR PROVISION}

Reform is required. Promoting access to humanity's cultural heritage and providing an interface with cultural life lies at the heart of the GLAM digitisation movement. Public interest considerations justify reshaping the contours of copyright within the GLAM sphere to reflect the utility underlying the services these institutions provide. ${ }^{136}$ Strengthening the ability of GLAMs to digitise reinforces society's right to participate in cultural life. Reform can be realised through re-evaluating the balance between proprietary interests and the public good, and easing the exacting constraints imposed upon institutions by copyright law.

Legislative reform can achieve this objective. Crafting a safe harbour for GLAM institutions is the appropriate policy response to the barriers to digitisation imposed by copyright law. Typically,

130 Susan Corbett "Digital v analogue: reconceptualising the orphan works problem for cultural heritage institutions" in Jessica C Lai and Antoinette Maget Dominicé (eds) Intellectual Property and Access to Im/material Goods (Edward Elgar Publishing, Cheltenham (UK), 2016) 289 at 289.

131 Ministry of Business, Innovation and Employment, above n 6, at 59.

132 Hudson and Kenyon "Digital Access", above n 32, at 42-43.

133 Susan Corbett "Regulation for Cultural Heritage Orphans: Time Does Matter" (2010) 2 WIPO Journal 180 at 187; Susan Corbett Archiving Our Culture in a Digital Environment: Copyright Law and Digitisation Practices in Cultural Heritage Institutions (New Zealand Law Foundation, December 2011) at 19-20; and Hudson and Kenyon "Without Walls", above n 66, at 208.

134 Susan Corbett "Copyright Norms and Flexibilities in the Digitisation Practices of NZ Museums", above n 73, at 62; and Susan Corbett "Digital v analogue", above n 130, at 292.

135 Korn, above n 4, at 18 .

136 Andrew F Christie "Cultural Institutions, Digitisation and Copyright Reform" (2007) 12 Media and Arts L Rev 279 at $290-291$. 
safe harbours are employed to protect internet service providers (ISPs) from copyright liability due to the infringing activities of their users. ${ }^{137}$ Yet, safe harbours are not confined to this context. A safe harbour is a narrow carve out from copyright liability that protects socially valuable conduct. Safe harbours are similar to copyright exceptions: they deem certain conduct permissible that would otherwise infringe copyright. ${ }^{138}$ Legislative protection is however contingent on the performance of certain conditions. ${ }^{139}$ Conditional protection reflects a decision that full copyright immunity is inappropriate, as it would unduly prejudice the interests of copyright holders.

Safe harbours thus allow a nuanced balancing of the rights of copyright owners against the interests of GLAMs in conducting digitisation. Imposing conditions on the operation of the safe harbour ensures that the rights of creators are adequately protected.

\section{A Sketching the Boundaries of the GLAM Safe Harbour}

The GLAM safe harbour ought to empower institutions to digitise collection items without fear of copyright liability. Creating a zone of permitted GLAM digitisation would overcome legal barriers to digitisation and avoid the practical consequences that flow from copyright law.

There is a mandate for reform. Institutions report that copyright owners often provide unremunerated licences to cultural institutions enabling them to digitise cultural works. ${ }^{140}$ Te Papa's licensing practices provide an apt illustration: 77 per cent of respondents agree to the model terms set out in the licence. ${ }^{141}$ These figures reveal that copyright norms within the GLAM sphere differ from the strict statutory reality. Authors and copyright owners are more comfortable granting digitisation licences than the legislation assumes. Readjusting the statutory defaults to reflect current copyright norms would bring law and practice into line. Modelling the foundations of the GLAM safe harbour on Te Papa's standard licensing terms is thus a coherent starting point.

The scope of the safe harbour should be formulated to allow GLAM institutions to:

- Make and store copies of the work.

- Reproduce the work in publications and educational materials. Examples of these mediums include social media channels such as Facebook, Instagram, Flickr and YouTube; catalogues; and online resources created for educational purposes.

137 See Copyright Act, s 92B.

138 Christophe Geiger "Promoting Creativity through Copyright Limitations: Reflections on the Concept of Exclusivity in Copyright Law" (2010) 12 V and J Ent \& Tech L 515 at 521.

139 See Copyright Act, s 92E.

140 Hudson and Kenyon "Digital Access", above n 32, at 25.

141 Leachman email regarding statistics on Te Papa's copyright licensing practices, above n 97. 
- $\quad$ Reproduce the work in online databases for the purpose of promoting access to cultural works and promoting the right to participate in cultural life.

- Make limited adaptions to the work necessary for reproduction, such as changing the resolution of virtual copies, and scaling the size of the image.

These functions must only be exercised for a non-commercial purpose. Exploiting a work for a commercial purpose falls outside the scope of the safe harbour.

A safe harbour formulated in this way would overcome the legal barriers and practical consequences imposed by copyright law. Culturally vibrant orphan works such as diaries, maps and oral histories would be available for digitisation and accessible to the public. Multi-layered complex works such as films could be digitised without having to navigate intricate licensing arrangements. Transaction costs would be significantly reduced, as institutions would no longer have to track down copyright owners and negotiate terms. The right to participate in cultural life would also be strengthened by providing public access to vast collections of cultural works and reversing the effects of the digital skew. ${ }^{142}$

\section{B Protecting the Interests of Copyright Owners}

Reform must empower institutions to take up digital technologies and better promote access to cultural works within a framework of reasonable copyright constraints. There is a balance to be struck. Exclusively shaping copyright law through a human rights prism could justify dismantling the copyright regime in order to fully realise laudable goals such as universal access to cultural works. Reform must be circumscribed to ensure copyright owners can continue to commercially exploit their creative works. Indeed, international human rights law requires states to protect intellectual property rights. ${ }^{143}$ Securing the right for authors to participate in private markets carves out zones of author autonomy, and promotes creativity and productive output. ${ }^{144}$ An unbounded GLAM safe harbour would interfere with these objectives. This article proposes three mechanisms to ensure commercial copyright interests are adequately protected.

142 New limitations and exceptions must comply with international obligations under the Berne Convention 1161 UNTS 3 (signed 9 September 1886, entered into force 5 December 1887) and annex 1C (Agreement on TradeRelated Aspects of Intellectual Property Rights) [TRIPS Agreement]. This article assumes that the proposed safe harbour is compliant. Further detailed analysis is beyond the scope of this article.

143 Universal Declaration of Human Rights, above n 51, art 27.

144 Laurence R Helfer and Graeme W Austin Human Rights and Intellectual Property: Mapping the Global Interface (Cambridge University Press, Cambridge, 2011) at 189. See generally Laurence R Helfer "Collective Management of Copyright and Human Rights: An Uneasy Alliance" in Daniel J Gervais (ed) Collective Management of Copyright and Related Rights (2nd ed, Kluwer Law International, Alphen aan den Rijn (The Netherlands), 2010) 75 at 75-77 and 81-85. 


\section{Restricting digitisation to out-of-commerce works}

Timeframe conditions ought to be imposed to limit interference with commercial exploitation of cultural works. Permitting digitisation of works that are still being commercially exploited would interfere with the economic rights of copyright owners. Contemporary novels, for example, ought not to be digitised: this would disrupt the book market by providing free access to commercial works. Digital business models are particularly vulnerable, as seen with the example of magazine companies: increasingly, magazine companies are digitising out-of-print publications. Subscribers pay a fee to access a virtual database of archived magazines. Often, libraries also house physical archives of magazines on behalf of the public. Enabling libraries to provide free digital access to magazine collections would undermine the digital business models employed by magazine companies. Digitisation therefore must be circumscribed to enable copyright owners to commercially exploit their creative works.

Confining digitisation under the GLAM safe harbour to out-of-commerce works protects economic interests. Out-of-commerce works are works that are no longer subject to mainstream commercial exploitation. ${ }^{145}$ Two categories of works fall within the scope of this criterion: firstly, works that were never created for the purpose of deriving revenue and were never "in-commerce"; 146 and secondly, works that are no longer being commercialised and have left their market behind. ${ }^{147}$ Before conducting digitisation, GLAM institutions should undertake (and document) reasonable efforts to ascertain whether the work is still being commercially exploited. Factors such as the length of time since the work was last commercialised, the extent of dissemination, ${ }^{148}$ the ostensible age of the work, the nature of the work and the extent of previous commercial use could help to indicate the status of the work. ${ }^{149}$ Works should only be digitised where the institution is satisfied that the work is no longer subject to commercial exploitation. This requirement would act as a filter to ensure GLAM institutions do not digitise clearly commercial works.

145 European Commission "Memorandum of Understanding (MoU) on Key Principles on the Digitisation and Making Available of Out-of-Commerce Works - Frequently Asked Questions" (press release, 20 September 2011) at 2 .

146 Hudson and Kenyon "Without Walls", above n 66, at 209.

147 At 209; and Justin Hughes "Fair Use Across Time" (2003) 50 UCLA L Rev 775 at 787.

148 Lois F Wasoff "If Mass Digitization Is the Problem, Is Legislation the Solution? Some Practical Considerations Related to Copyright" (2011) 34 Colum J L and Arts 731 at 737-738; and David Nimmer "Submission to the Section 108 Study Group" at 8-10.

149 United States Copyright Office Report on Orphan Works: A Report of the Register of Copyright (January 2006) at 9-10. 
Permitting digitisation of out-of-commerce works raises fundamental questions regarding the nature of copyright. Critics claim that permitting copying of out-of-commerce works expropriates the rights of authors to control the dissemination of their creative products. Derogating from authors' exclusive rights is thus seen by some to be an impermissible intrusion on "sacred and indefeasible" intellectual property rights. ${ }^{150}$ Proponents of this view misconceive the origins and nature of copyright. Copyright is not an absolute property right: rather, it is a legislative regime designed to solve a market failure. ${ }^{151}$ Free copying undercuts economic incentives for the generation of new works, as authors are unable to recoup the costs incurred during the creative process. ${ }^{152}$ Statutory proprietary rights are granted to authors to resolve this market failure and secure the continued generation and diffusion of cultural works. ${ }^{153}$ Copyright has been only grudgingly accepted for this purpose. ${ }^{154}$ Burdening works with proprietary rights in circumstances where the rationale of copyright does not apply "choke[s] off" dissemination of cultural works and threatens the progress of cultural life. ${ }^{155}$ Accordingly, copyright should afford authors "control no greater than strictly necessary to induce the author to perform his part of the social exchange." ${ }^{156}$ Reforming copyright's traditional contours to achieve this balance is justified. Otherwise, the public interest in access to cultural works is subjugated by the rights of copyright owners in a way that is inconsistent with copyright's ontological roots.

Out-of-commerce works ought not to be subject to full copyright protection within the GLAM sphere. Prohibiting digitisation of out-of-commerce works creates a new market failure by preventing access to works that are no longer readily available through commercial channels. Digitising out-ofcommerce works resolves this failure by enabling public access, which is a central goal of copyright law. ${ }^{157}$ Permitting out-of-commerce works to be digitised also does not interfere with economic incentives for the generation of new creative works. This is because there no longer exists a market

150 See (5 February 1841) 56 GBPD HC 344.

151 Liu, above n 5, at 1508; and Frankel, above n 5, at 201-204.

152 Liu, above n 5, at 1508; and William M Landes and Richard A Posner The Economic Structure of Intellectual Property Law (Harvard University Press, Cambridge (Massachusetts), 2009) at 40-41 and 57.

153 Liu, above n 5, at 1508; Lepage, above n 9, at 3-4; Jane C Ginsburg "A Tale of Two Copyrights: Literary Property in Revolutionary France and America" (1990) 64 Tul L Rev 991 at 992-993 and 998-1002; and Frankel, above n 5, at 201-204.

154 (5 February 1841) 56 GBPD HC 348; and Ginsburg, above n 153, at 993.

155 Harper and Row Publishers Inc v Nation Enterprises 471 US 539 (1985) at 589.

156 Ginsburg, above n 153, at 993.

157 At 992 
in which out-of-commerce works can be commercially exploited. ${ }^{158}$ Enabling digitisation is therefore not an unreasonable intrusion on the rights of copyright owners. The use of out-of-commerce frameworks in overseas jurisdictions lends support to this conclusion. The US Copyright Term Extension Act 1998 is one example: 159

... during the last 20 years of any term of copyright of a published work, a library or archives, including a nonprofit educational institution that functions as such, may reproduce, distribute, display, or perform in facsimile or digital form a copy or phonorecord of such work ... for purposes of preservation, scholarship, or research[.]

Qualifying institutions can rely on this exception where they have conducted a reasonable investigation to ensure that the work is no longer subject to normal commercial exploitation, the work cannot be obtained at a reasonable price, and that the copyright owner has not provided notice that the work is unavailable for use. ${ }^{160}$ Similarly, the European Union has proposed collective licensing mechanisms to facilitate digitisation of out-of-commerce works. ${ }^{161}$ Works that meet the out-ofcommerce requirement can be digitised. An out-of-commerce requirement for the New Zealand GLAM safe harbour protects commercial copyright interests while also unlocking vast collections of works for digitisation.

\section{Opt-out mechanism and ongoing protection}

Copyright owners ought to be able to prevent digitisation by opting-out of the GLAM safe harbour. Opt-outs are increasingly employed in copyright law to secure important policy objectives. ${ }^{162}$ Requiring copyright owners to opt-out of a particular regime - as opposed to opting-in - provides sufficient protection while also limiting the interference of copyright with public policy. ${ }^{163}$ Owners of presently commercialised works ought to be able to opt-out of the safe harbour to prevent GLAM digitisation from interfering with their commercial endeavours. Upon receipt of notice of a copyright owner's decision to opt-out, GLAM institutions should refrain from digitising the particular

158 Hudson and Kenyon "Without Walls", above n 66, at 209.

159 Sonny Bono Copyright Term Extension Act Pub L No 105-298 § 104, 112 Stat 2827 at 2829 (1998). See also 17 USC $\S 108$.

160 At 2829 . See also 17 USC $§ 108$.

161 European Commission Proposal for a Directive of the European Parliament and of the Council on Copyright in the Digital Single Market (COM(2016) 593, September 2016) at 26-27; and Lucie Guibault "Intellectual Property and Culture" in A Kamperman-Sanders and others (eds) Introduction to Intellectual Property and Knowledge Management (Maastricht University, Maastricht (The Netherlands), 2018) at 6 (forthcoming).

162 Travis, above $\mathrm{n} 11$, at 335 .

163 At 335 
work, or remove the work from online forums. ${ }^{164}$ Injunctive relief can be sought where institutions fail to comply.

Creating an opt-out mechanism provides commercial copyright owners with ongoing protection. It is not anticipated that the opt-out will be widely utilised for two reasons. Firstly, permitting digitisation under the GLAM safe harbour aligns with copyright norms as authors already regularly allow GLAMs to digitise their works. ${ }^{165}$ Secondly, the out-of-commerce requirement limits interference with commercial copyright exploitation, reducing the need for copyright owners to utilise the opt-out mechanism.

Nevertheless, introducing an opt-out mechanism is required to provide ongoing protection of commercial copyright interests. Digitising out-of-commerce works creates new opportunities for these works to be re-discovered. Copyright owners may seek to re-commercialise their works in these circumstances; GLAM digitisation should not prevent them from successfully doing so. Providing an opt-out preserves the opportunity for copyright owners to exit the safe harbour and re-commercialise their works. Similarly, the safe harbour assumes that the authors of orphan works would not object to digitisation, as their works were not created for the purposes of economic exploitation. ${ }^{166}$ Where these authors emerge and do seek to commercialise their works, an opt-out secures the opportunity to do so. Finally, an opt-out preserves freedom of contract. Copyright owners or collective licensing bodies who object to the scope and operation of the safe harbour can opt-out and negotiate separate digitisation licences with GLAM institutions on their own terms.

Opt-out mechanisms have been implemented in overseas GLAM reform models. Europe's proposed licensing mechanism for out-of-commerce works is one example. Under this system, collective rights management organisations (CMOs) negotiate with GLAMs to formulate licence terms governing the digitisation of out-of-commerce works. ${ }^{167}$ Once settled, the terms automatically extend to bind all copyright owners within a particular category of works unless they exercise their right to opt-out. ${ }^{168}$ Placing the burden on copyright owners to object to digitisation establishes an opt-

164 See generally A\&M Records Inc. v Napster Inc 114 F Supp 2d 896 (ND Cal 2000); affirmed in part, reversed in part 239 F 3d 1004 (9th Cir 2001).

165 Hudson and Kenyon "Digital Access", above n 32, at 25.

166 Hudson and Kenyon "Without Walls", above n 66, at 209. See also Liu, above n 5, at 1501.

167 Guibault, above n 161, at 4-6.

168 European Commission "Memorandum of Understanding", above n 145, at 2-3; and Guibault, above n 161, at $4-6$. 
out regime. The US Copyright Terms Extension Act 1998 also includes an opt-out. ${ }^{169}$ Qualifying institutions are barred from digitising works where the owner has provided notice that the work is presently being commercially exploited or is available at a reasonable price. ${ }^{170}$ Copyright owners can thus opt-out of the statutory exception. More generally, opt-outs have been employed in the European framework for orphan works, ${ }^{171}$ as a tool for regulating the conduct of ISPs,${ }^{172}$ and as part of the Google Books settlement. ${ }^{173}$ Opt-outs protect commercial copyright interests, promote socially beneficial activities, and contribute to the creation of cultural democracy by unlocking works for digitisation. ${ }^{174}$

\section{Additional safe harbour conditions}

Imposing additional conditions on the operation of the safe harbour is the final protective measure for commercial interests. Restricting digitisation to non-commercial purposes is the principal condition. The safe harbour is not directed at enabling GLAMs to exploit copyright-protected works for their own commercial gain. Uncompensated digitisation is permitted solely as a vehicle for strengthening the right to participate in cultural life. Commercial exploitation does not accord with this goal. Institutions therefore ought to lose their statutory protection when they intend to derive direct financial benefits from digitisation.

GLAMs should also be required to undertake reasonable efforts to educate users of the copyright status of digitised works. Existing databases already provide information about the permissible uses of digitised works, publish information regarding copyright licences and operate a system enabling users to obtain licences to re-use digitised works. ${ }^{175}$ Formalising this as a statutory requirement would ensure that users are aware of the copyright protections that exist over digitised works.

169 Sonny Bono Copyright Term Extension Act Pub L No 105-298 § 104, 112 Stat 2827 at 2829 (1998). See also 17 USC $\$ 108$.

170 At 2829 . See also 17 USC $§ 108$.

171 Directive 2012/28/EU of the European Parliament and of the Council of 25 October 2012 on certain permitted uses of orphan works [2012] OJ L 299/5.

172 See generally A\&M Records Inc v Napster Inc 114 F Supp 2d 896 (ND Cal 2000); affirmed in part, reversed in part 239 F 3d 1004 (9th Cir 2001); Kelly v Arriba Soft Corp 336 F 3d 811 (9th Cir 2003); and MetroGoldwyn-Mayer Studios Inc v Grokster Ltd 545 US 913 (2005). See also Travis, above n 11, at 356.

173 Wasoff, above n 148, at 391-393.

174 Oren Bracha "Standing Copyright Law on Its Head? The Googlization of Everything and the Many Faces of Property" (2007) 85 Tex L Rev 1799 at 1849-1855; and Jonathan Band "The Google Library Project: Both Sides of the Story" (2006) 1 Plagiary 6 at 19.

175 See Auckland Museum "Rights and Permissions" <www.aucklandmuseum.com>. 
Reasonable protective measures ought to be employed to prevent unauthorised copying of digitised works. One option could be to protect digitised works through the terms of use governing access to virtual databases. Terms of use can create enforceable contractual obligations that regulate how users interact with databases and impose downstream restrictions on the use of digitised works. ${ }^{176}$ Overseas institutions include terms prohibiting the reuse of works without express consent from the copyright owner. ${ }^{177}$ Breach of these terms could result in legal action by the aggrieved GLAM institution to protect the copyright owner's rights. Technological measures may also serve to protect copyright works: ${ }^{178}$ institutions could embed copyright data in digitised works to deter unauthorised copying, prevent right-click copy functionality, or only publish low-resolution versions of digitised works. ${ }^{179}$

\section{Te Ao Māori, Tikanga and Consultation}

Cultural heritage institutions have a responsibility to respect te ao Māori and tikanga and this principle ought to be enshrined as a safe harbour condition. GLAM institutions already attempt to adhere to tikanga when digitising Māori cultural property. ${ }^{180}$ Constructing a safe harbour condition secures legislative protection for Māori cultural rights and gives effect to the idea that copyright ought to interface with Māori customary law. ${ }^{181}$

Consultation with kaitiaki is a central requirement under the safe harbour. Māori customary law seeks to protect and preserve cultural heritage for the use of customary groups and future generations. ${ }^{182}$ Tikanga Māori secures this objective through kaitiakitanga. ${ }^{183}$ Kaitiaki are the physical and spiritual guardians of taonga works and are entitled to "the benefits of the cultural and

176 Kenneth D Crews "Museum Policies and Art Images: Conflicting Objectives and Copyright Overreaching" (2012) 22 Fordham Intell Prop Media \& Ent LJ 795 at 807-808.

177 At $807-808$.

178 Museum of New Zealand Te Papa Tongarewa Copyright and Museums: Governance, Management and Planning, above n 6, at 14.

179 At 14.

180 See Michaela O'Donovan and Zoe Richardson "Navigating good practice image permissions for Māori collections held at Auckland War Memorial Museum - Tāmaki Paenga Hira" in Hēmi Whaanga, Te Taka Keegan and Mark Apperley (eds) He Whare Hangarau Māori: Language, Culture and Technology (University of Waikato, Hamilton, 2017) 165 at 172-177.

181 See generally Frankel, above n 5, at 116-119.

182 Jessica C Lai Indigenous Cultural Heritage and Intellectual Property Rights: Learning from the New Zealand Experience? (Springer, New York City, 2014) at 61.

183 At 230 
spiritual sustenance therefrom". ${ }^{184}$ Decisions regarding virtual access to digitised taonga therefore ought to be made by kaitiaki. Consultation ensures that Māori rights are respected and enriches Māoriinstitution relationships by fostering a climate of shared decision-making. The Wai262 Report provides a useful consultation framework. ${ }^{185}$ According to the Waitangi Tribunal, taonga works deserve the greatest protection: kaitiaki are empowered to object to derogatory treatment and consent should be sought for any commercial uses. ${ }^{186}$ Taonga-derived works are similarly protected. ${ }^{187} \mathrm{~A}$ lesser standard is justified for mātauranga Māori. ${ }^{188}$

Virtual databases of Māori cultural works should be operated in compliance with tikanga. Specific consideration should be given to the virtual treatment of taonga works. Currently, copyright law protects moral rights by enabling authors to object to derogatory treatments that are "'prejudicial to the honour or reputation' of the author." ${ }^{189}$ Authors are not empowered to object to treatments that affront cultural or spiritual values. ${ }^{190}$ GLAM institutions should be required to think beyond these constraints. This could include measures such as publishing online guidance instructing users how to interact with taonga works respectfully, allowing access only upon request, or confining digitisation solely for research and education. ${ }^{191}$

Māori cultural works that have fallen into the public domain ought to be subject to the same protections. Property law encompasses both ownership and stewardship interests. ${ }^{192}$ Ownership rights must be balanced against the rights of kaitiaki over their cultural property. Infusing tikanga into the GLAM safe harbour ensures that guardianship concerns can be "taken into account in the realm of property" regardless of the copyright status of the work. ${ }^{193}$

184 At 230.

185 Waitangi Tribunal Report of the Waitangi Tribunal on Claims Concerning New Zealand Law and Policy Concerning New Zealand Law and Policy Affecting Māori Culture and Identity (Wai 262, 2011).

186 At 84 .

187 At 85 .

188 At 86

189 Lai, above n 182, at 87.

190 At 87. But see Frankel, above n 5, at 147.

191 O'Donovan and Richardson, above n 180, at 172-177.

192 Lai, above n 182, at 224

193 At 225 . 


\section{Distinction from Alternative Reform Approaches}

A safe harbour is not the only means by which copyright reform can be achieved. Two alternative models have been proffered by reform agencies to enable digitisation of copyright works: Extended Collective Licensing (ECL) and the orphan works regime. Constructing a fit-for-purpose safe harbour is, however, the most appropriate legal response to the copyright barriers faced by New Zealand's GLAM institutions. The following analysis explains why the alternative models are unfit when compared with a safe harbour regime.

\section{Extended Collective Licensing model}

ECL models enable collective rights management organisations (CMOs) representing copyright owners of particular categories of works to negotiate licence terms. Once the terms are settled, CMOs are authorised to issue licences to GLAMs permitting digitisation of all works falling within the specified category. ${ }^{194}$ Notwithstanding its adoption by numerous countries, this model is inherently constrained due to the strict requirements for recognising a CMO. These include proof that the CMO possesses a mandate from the majority of rights holders and controls a significant number of rights holders' works. ${ }^{195}$

Often, in the GLAM context no identifiable body of rights holders exists that is capable of forming a qualifying CMO. Social history works are particularly ill suited to an ECL model because the authors, and number, of these works are typically unknown, rendering it difficult to determine the mandate of any proposed CMO. Permitting works to be digitised only after a CMO has successfully negotiated licence terms thus limits the scope of works available for digitisation. Such issues do not arise under a safe harbour approach.

\section{Orphan works regime}

The protections afforded under the orphan works regime are triggered once the user conducts a diligent search in good faith to locate the orphan's lost rights holder. ${ }^{196}$ These search efforts are typically documented by the user and captured in a database, which aids future searches. Following a qualifying search, the user is permitted to use the copyright work. If the rights holder comes forward,

194 United States Copyright Office Orphan Works and Mass Digitisation: A Report of the Register of Copyrights (June 2015) at 82-84.

195 At 90.

196 Corbett "Digital v analogue", above n 130, at 308-309. 
the user's liability is limited to the payment of a reasonable licence fee. ${ }^{197}$ Injunctive relief may still be sought by the rights holder to restrain future use of the orphan work. ${ }^{198}$

Orphan works regimes are less effective than a fit-for-purpose GLAM safe harbour. Firstly, compliance with the diligent search requirement generates prohibitive costs. ${ }^{199}$ Some regulatory frameworks require users to search over 40 databases before an individual orphan newspaper article can be digitised ${ }^{200}$ Requiring GLAMs to ascertain whether a work is out-of-commerce - as proposed in this article - is likely an easier and less expensive exercise. Similar to orphan works models, this approach will generate databases of information documented by GLAMs in their efforts to ascertain whether the work is truly out-of-commerce. Secondly, the compensation requirement is onerous. Not only must GLAMs pay to conduct diligent searches but they must also establish "insurance" funds to pay rights holders should they emerge seeking compensation. This approach undermines business certainty and discourages GLAM investment in digitisation projects. ${ }^{201}$ Finally, the proposed GLAM safe harbour removes the injunctive power. Injunctive relief undercuts GLAM digitisation by barring the continued use of digitised works, or enabling rights holders to extract higher licence fees.

Constructing a GLAM safe harbour is justified as it reflects the value society attaches to the right to participate in cultural life and the ability to access digitised cultural works. Forgoing the diligent search, compensation and injunctive relief elements of the orphan works regime better enables GLAMs to pursue these objectives.

\section{CONCLUSION}

Galleries, libraries, archives and museums deliver powerful societal benefits. Increasingly, GLAM institutions are turning to digital technologies to promote access to cultural works. Online databases, social media and other technologies enable GLAMs to transcend physical institutional constraints and enhance engagement and participation in cultural life. New Zealand's copyright framework currently prohibits unauthorised digitisation. Legal barriers to digitisation create significant primary and secondary costs and distort the culture to which society is exposed. These limits are unjustified.

Creating a GLAM safe harbour is required to empower institutions to employ digitisation technologies with greater freedom. The case for reform is strong. Reshaping copyright's traditional contours to permit digitisation strengthens the right to participate in cultural life and remedies societal

197 United States Copyright Office Orphan Works and Mass Digitisation, above n 194, at 63-64.

198 At $67-68$.

199 Susan Corbett "Digital v analogue", above n 130, at 300-301.

200 See for example United Kingdom Intellectual Property Office Orphan works diligent search checklist: Literary Works (November 2015).

201 Susan Corbett "Digital v analogue", above n 130, at 300-301. 
harms inflicted by the copyright regime. The safe harbour does not prejudice commercial copyright interests. Imposing conditions on the operation of the safe harbour ensures that the right to commercially exploit copyright-protected works is not disturbed. Compliance with tikanga and Māori customary law is also required under the proposed reform. The safe harbour thus strikes an appropriate balance between the interests of creators, copyright owners, kaitiaki and the public.

Society needs to be forward looking. Reform will breathe new life into cultural works, reinvigorate participation in cultural life, and enrich the cultural fabric of society. New Zealand should seize the present reform opportunity and act now.

\section{ADDENDUM}

Since writing this article, the Ministry of Business, Innovation and Employment has published its Issues Paper on the Review of the Copyright Act $1994 .{ }^{202}$ Encouragingly, the Ministry noted the copyright difficulties faced by libraries and archives seeking to undertake mass digitisation projects. However, the Ministry did not discuss reform in great depth, nor did it comprehensively comment on the role of galleries and museums in digitising cultural works for the public benefit. The Ministry is likely to assess GLAM reform in greater depth in its final Report.

202 Ministry of Business, Innovation and Employment Review of the Copyright Act 1994: Issues Paper (November 2018). 